\title{
Reforming for Performance and Trust: Some Reflections
}

Geert Bouckaert $^{1}$

(Core speech at the NISPAcee conference, Varna, Bulgaria, 2011)

When OECD was taking stock of public-sector reforms in 2005 for its ministerial conference, it summarised six shifts in the practices of its member-countries (OECD 2005) and it put trust on its agenda. Governments became open governments, enhancing public-sector performance, and modernising accountability and control. They also reallocated and restructured tasks and organisations, using market-type-mechanisms (MTM), and they organised and motivated public servants as part of modernising the public-employment function. There was an awareness that trust was a key driver and an objective of public-sector reform policies, even if the causal linkages were not clear and rather indirect (Van de Walle et al. 2005).

The economic and financial crisis has pushed Western OECD countries to cutback management and to savings, but has also pushed them towards an awareness that trust in the capacity of governments and its public sector to realise effective policies is a crucial element in a performing society and economy. At the 2010 OECD ministerial conference, a key starting point was that "trust, built on openness, integrity, and transparency, remains an overarching goal to foster an effective and performance-driven public sector, delivering better public services more efficiently, and promoting open and transparent government" (OECD 2011a; see also OECD 2011b). Building and keeping trust remains even more an objective in a period of crisis, where the public sector needs to be a stronghold in the economy and in society.

1 Professor, EGPA Immediate Past President, IIAS Programme and Research Advisory Committee Chairman (European Group for Public Administration, International Institute of Administrative Sciences), Katholieke Universiteit Leuven, Leuven, Belgium. 


\section{Reforms to build performance and trust}

Three key challenges within OECD have been turned into three operational questions to cope with the crises: How do countries respond to the main challenges, especially in delivering better public services under fiscal pressure? How to get towards a more effective and performance-oriented public service? And how to promote an open and transparent government? (OECD 2011a). From these questions, and partly also from the stated responses, the two existing logics: logics on causality for results (a logic of consequences), and logics on values and identities (a logic of appropriateness) are surfacing public administration reform policies and agendas.

The first question on how to guarantee service delivery in times of fiscal pressure addresses three topics. Next to the classical answers, i.e. to engineer economic, efficient and effective processes and services, the focus on IT and on innovation tries to realise "more with less". However, this "more with less" rhetoric is often transformed into two other scenarios: do the same with less, or do less with much less (which is a shrinking scenario). Since performance is not just results but also presenting results, communicating results helps to meet expectations and support an agenda to build and keep trust in the capacity of the public sector to deliver. Finally, sustainability of service delivery implies that the public sector needs to engage with the public and its stakeholders. This means that increasingly, public-service delivery includes, involves and mobilises citizens/customers, the private sector, civil society with its NGOs, and also local government.

However, there seems to be a mechanism to decentralise savings to local governments (Bouckaert et al. 2011). This may affect the capacity of local governance.

\section{Table 1}

Reaction of EU local governments to the global financial-economic crisis

\begin{tabular}{|l|c|}
\hline Delay/postponement of investments & 19 \\
\hline $\begin{array}{l}\text { Budget cuts: decrease of expenditure/spending related to management functions } \\
\text { (e.g. office supplies, staff training) }\end{array}$ & 18 \\
\hline Budget cuts: decrease of expenditure/spending related to debt & 18 \\
\hline $\begin{array}{l}\text { Budget cuts: decrease of expenditure/spending related to service delivery (e.g. } \\
\text { reducing hours of teaching in schools, lowering subsidies for child care, ...) }\end{array}$ & 15 \\
\hline $\begin{array}{l}\text { Decrease of local government staff numbers (e.g. lay-offs, early retirement schemes, } \\
\text { non-replacement of pensioning staff members, reduction of salaries, others) }\end{array}$ & 13 \\
\hline Restructuring/reorganization initiatives without reduction of local staff numbers & 10 \\
\hline Restructuring/reorganization initiatives leading to reduction of local staff numbers & 9 \\
\hline Increase of local tax levels (e.g. increase of surcharge on income tax, property tax, ...) & 8 \\
\hline $\begin{array}{l}\text { Restructuring/reorganization initiatives in which tasks and/or services are } \\
\text { transferred to other organizations }\end{array}$ & 5 \\
\hline
\end{tabular}

Source: Bouckaert et al. 2011, 23. 
How have local governments reacted and responded to the global financialeconomic crisis in order to be able to continue to guarantee local government's missions? Table 1 displays reactions of local governments within the EU to the financial-economic crisis. The decreasing number of countries that use a particular "answer" is shown out of the 23 countries that responded to the survey. The results show that local governments have reacted in various ways to the challenges the financial-economic crisis has triggered. Most common seem to be those initiatives that limit the expenditures, either by postponing investments or directly cutting the budget. Next come the indirect savings, like decreasing government staff numbers and organisational restructuring, sometimes leading to reductions of staff. Increases of local tax levels (the revenue side) and restructuring initiatives with transfers of tasks to other organisations are the reactions which occur the least.

To address the challenge of guaranteeing a more effective and performanceoriented public service which is sustainable, three major strategies are being developed which focus on strategic management which matches expectations, but which takes resources into account and reaches out to external stakeholders.

Finally, an open and transparent government serves a double objective. It provides a key vehicle to restoring trust in government and to aligning the public sector with modern information-management practices. Also, it provides policy levers to facilitate capacity for change and for sustainable efficiency and effectiveness reforms in the public sector.

For all these agendas, trust is a crucial concept to support performance (Van Dooren et al. 2010). Three major models seem to emerge in this reality of publicsector reforms: New Public Management (NPM), the Neo Weberian State (NWS) and New Public Governance (NPG) (Pollitt and Bouckaert 2011). The diversity of the three models, which is the result of path dependencies and different choices of political systems, includes a diversity towards trust as a component, a driver and an objective in these models.

In the next section, three models of how performance and trust could be related are discussed.

\section{How could trust work? Three models of performance and trust}

There are three models which connect performance and trust (Bouckaert and Halligan 2008): a push/pull model, a driver model and a circular model (Halligan and Bouckaert 2009). 


\section{A push/pull model of trust}

Trust could be at the end, as a result, of the performance chain (graph 1). However, this is a conditional result. Trust becomes a dependent variable. This may occur at the micro level (service delivery of a specific public-sector organisation, depending also on the perception and expectations of customers), and at the meso level (depending also on effectiveness and outcomes of policies).

There is an asymmetrical link. An improving level of output and outcome will not necessarily lead to higher trust levels; however, a deteriorating level of output and outcomes almost certainly will put trust under pressure and may cause a decline, especially if scandals or catastrophes also occur. In this logic, the chain of input-activities-output-outcome is pushing trust. Trust is the dependent variable and an effect of the input-outcome chain, which is the independent variable or the cause. However, this link is conditional and potentially loose, almost like a Grand Canyon (Bouckaert and Halligan 2008).

There is probably a reverse mechanism active where trust influences certain types of outcomes. For the same level of output (quantity and quality), one could assume that outcomes ceteris paribus will be higher if trust levels are higher. For example, if parents trust teachers and schools, if students trust their teachers, school outcomes may be higher for equal levels of school output; if patients trust doctors and hospitals, hospital outcomes may be higher for equal levels of hospital output; if citizens trust the police and the judicial system, police outcomes may be higher for equal levels of police output.

Obviously this is policy field-related (trust in the educational system, in the health system, in the security system). This causality may be weaker or less certain for general administration functions such as e.g. inspections, permits, subsidies or communication. Here, outcome is not pushing trust but trust is pushing outcomes. It is as if trust is pulling its outcome. As there is more trust, outcomes will be pulled upward for e.g. education, security or health outcomes.

\section{Graph 1}

Push/pull model of trust

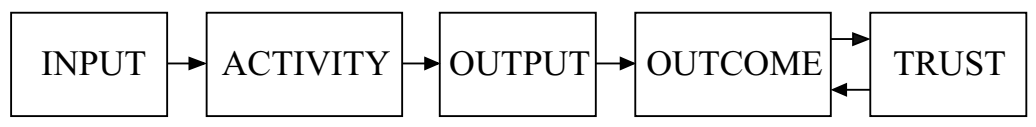

\section{A drivers model of trust}

In the push/pull model, trust is conceived as being at the end of a chain, but actually, trust could also be at the beginning of a causal chain. The performance chain has a trust-driver. 
If citizens trust their public-sector organisations or specific policies, or the public sector as such, then it is quite probable that there is a willingness to pay (fees, contributions, taxes) or to support a policy, or a system, or citizens are willing to work for the public sector (public sector/service motivation). Trust is the first stage of the causal chain and helps to explain the level of input at all levels. At the micro level, it creates a willingness to use the system, to follow regulations. There is a willingness to choose ceteris paribus for public education, security, health, and to allocate budgets to these policy fields, rather than opting for private education, security or health. There is a willingness to support policies at the meso level. There is a conviction at the macro level that the system needs to be supported actively.

If there is no trust, there is a downward pressure to put less money into that system. But also, trust is crucial for citizens to consider working for the government. The attractiveness of government on the job market is obviously complex and depends on the pressure on the labour market, but also on civil-service and civil-servant motivation, prestige and trust. From that point of view, the attractiveness of the public service on the job market could be a useful indicator. Also the position of volunteers in government is an important indicator for a trustworthy government and civil service. Related to this is the issue of co-production in government, which again requires trust from citizens, NGOs and the private sector in government and vice-versa.

This becomes increasingly important for the future production models in the public sector. In this case, trust becomes an independent variable and the inputoutcome chain becomes the dependent variable. This is not just a feedback loop (directly or indirectly), but a separate and first box in the chain as in graph 2.

\section{Graph 2}

Driver model of trust

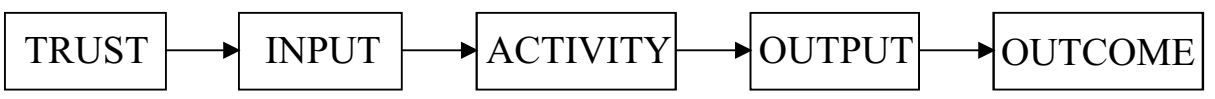

\section{A circular model of trust}

In a cyclical view (graph 3), thus not a linear chain view, trust becomes a dependent and independent variable at the same time. An empirical question is whether or not the input-activities-output-outcome chain is a closed box, and to what extent the separate parts have a direct impact on the trust level. The (reputation of the) quality of the employees could have an impact on the trust levels, or the quality of the service delivery could have an impact on the trust levels of society in the public sector. The public's perception of the public-sector trust in society (we trust them because they trust us; we do not trust them because they do not trust us) and of trust within the public sector (we trust them because they trust one another within the public 
sector; we do not trust them because they do not trust one another within the public sector), may also influence citizen's trust in the public sector.

This is one reason why trust is conceptually difficult to interpret; however, it is possible, analytically, to distinguish between the three models. In the push/pull model, trust is the ultimate impact of the outcome but also has a pull potential on the outcome. In the driver model, trust is a leverage for the input-outcome chain. In the circular model, both are combined.

In reality, trust probably may take these three forms simultaneously, and they are in interaction. Trust is cause, effect, intermediate and interacting variable, which makes it a challenge for modelling, but even more for developing a trust policy in an improvement strategy (Rousseau et al. 1998).

\section{Graph 3}

Circular model of trust

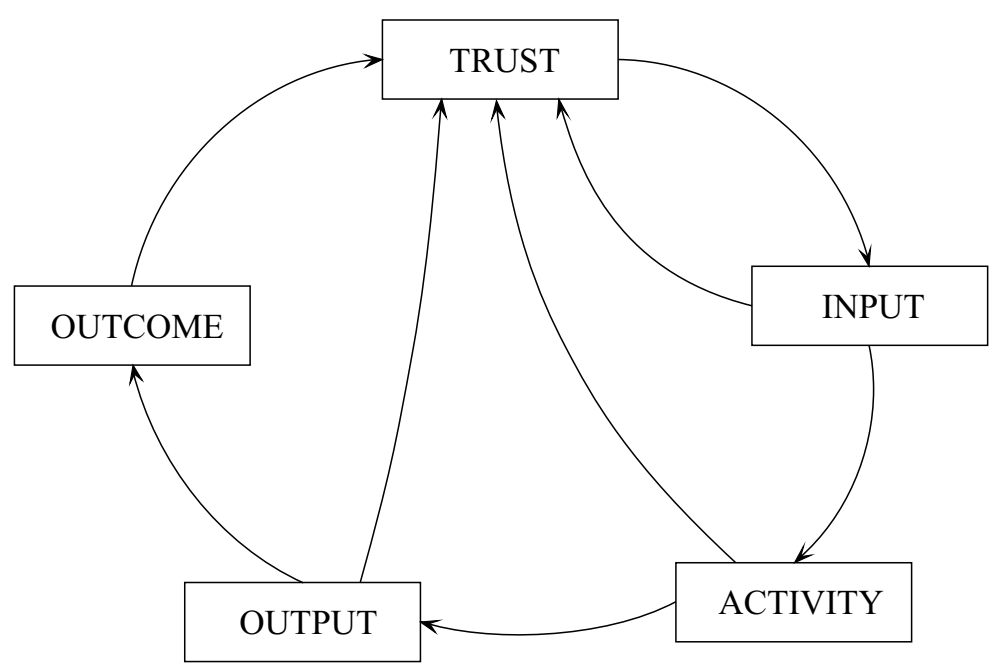

\section{Varying trust regimes}

In literature, there are many typologies, models and theories regarding types of trust. In many cases, there are overlaps in the classifications: "contractual trust" vs. "competence trust" vs. "goodwill trust" (Sako 1992), or "calculus-based trust" vs. "knowledge-based trust" vs. "identification-based trust" (Lewicki and Bunker 1996), or "deterrence-based trust" vs. "calculus-based trust" vs. "relational trust" vs "institutional trust" (Rousseau et al. 1998), or "ability-based trust" vs. "benevolence-based trust" vs "integrity-based trust" (Muthusamy and White 2005). 
There are also different qualifications and trust features related to trustworthiness, such as reliability, predictability, fairness, ability, willingness, consistency, competence, routine, identity, benevolence, and integrity. This makes the trust-research agenda complex and disconnected.

In this article, we refer to Rousseau et al. (1998). They distinguish between four types of trust, which in fact they reduce to three types. "Deterrence based trust" is not necessarily to be considered as trust since deterrence is part of a control system and therefore, by definition, it is not trust. Trust is a substitute for control. Deterrence could become part of a distrust system.

In general, "trust is an ongoing, market-oriented, economic calculation whose value is derived by determining the outcomes resulting from creating and sustaining the relationship relative to the costs of maintaining or severing it" (Lewicki and Bunker 1996, 120). This calculus-based trust is also described as deterrence-based trust, since this trust "is sustained to the degree that the deterrent (punishment) is clear, possible, and likely to occur if the trust is violated" (Lewicki and Bunker 1996, 119).

The three remaining types of trust are "calculus-based trust", "relational trust" and "institutional trust". These trust regimes become relevant as a context and driver of public-sector reform (Van de Walle 2011).

\section{Institution-based trust regime}

Institution-based trust refers to broad support systems that guarantee for risk levels to be acceptable and for trust cultures to remain. Legal systems may be considered to be part of control systems, but they may also feed trust. A professional and bureaucratic context could be considered as such an institution-based trust system. Accommodating rules and regulations brings rewards and promotion; violating rules and regulations brings expulsion and isolation. This is an economic-psychological reading of an administration. Violations of institution-based trust will result in redefining rules, regulations and penalties to make them more predictable, with a higher chance and predictability of following the rules instead of violating them.

In an institution-based public sector, the trust of citizens in the public sector could be strengthened and maintained by defining clear rights and duties, by defining and communicating dos and don'ts, and by connecting to citizens. This may enhance a vision of a legitimate, predictable, fair and trustworthy public sector. The trust of the public sector in society and its citizens could be strengthened by showing professional bureaucracy and demonstrating a clear legal handling of procedures resulting in fair decisions with a transparent and due process. Developing a state-of-law-based charter which protects citizen rights also supports this trust. Trust within the public sector could be enhanced by emphasising internal loyalty for the public sector and its organisations, but also by equilibrating process 
and performance. In general a Weberian, or Neo-Weberian hierarchical system of a traditional bureaucracy could match this regime.

\section{Calculus-based trust regime}

Calculus-based trust is grounded in rational choice and economically defined exchange. A solid knowledge about the economic calculus for transactions and exchange within relationships is crucial. A transparent performance calculus determines trustworthiness. Performance information is also trustworthy because it is audited.

This means that "information contributes to the predictability of the other, which contributes to trust. ... Regular communication puts a party in constant contact with the other, exchanging information about wants, preferences, and approaches to problems." (Lewicki and Bunker 1996, 121).

Violations of calculus-based trust are solved by collecting more knowledge and information, and reducing the chances of not perceiving violations. When there is a problem with indicators, more indicators will be generated; when there is a problem with standards, more standards will be developed; when there is a problem with audit, more audit will be the result.

In a calculus-based public sector, the trust of citizens in the public sector could be strengthened and maintained by communicating collected data on expectations, perceptions, satisfaction, and trust itself. The trust of the public sector in society and its citizens could be maintained and improved by developing market-based charters to empower customers; by communicating performance benchmarking; by making quality models explicit. Trust within the public sector includes all measures taken to measure performance, to audit the measured performance and to use it to guide, steer, control and evaluate. In general, the New Public Management with its performance drivers and market-type-mechanisms in its ideal design should be close to this regime.

\section{Relational trust regime}

Relational trust is based on information from within a relationship and is therefore sometimes labeled affective or identity-based trust, which also refers to good faith in a relationship. "We" becomes an important concept. In general, this trust is closely based on identification with desires, intentions, mutual understanding, group-think and shared objectives of these groups and their organisations. Violations of relational trust refer to values that ground the relation and the group bonding. They may be solved by restating values and common grounds for collaboration.

In a relational trust regime citizens' trust could be influenced by a willingness for partnerships, co-production, volunteering, public-service motivation and sharing policy objectives of the public sector and society. The trust of the public sector in 
society and its citizens could be strengthened by a public sector which accepts and pushes for co-design, co-decision, co-production and co-evaluation. Allowing volunteers is also an important element to corroborate this trust. Finally, trust within the public sector is all about trusting partnerships within the public sector within and between all levels and organisations. In general, New Public Governance with its networked ideal type should be close to this regime.

The implications of these three trust regimes for the three trust types can be described as in Table 2.

Table 2

Three Trust regimes (Institutional, Calculus and Relational) and three relationships.

\begin{tabular}{|c|c|c|c|}
\hline $\begin{array}{c}\text { Trust } \\
\text { Regimes }\end{array}$ & Identity-based Trust & $\begin{array}{c}\text { Calculus-based } \\
\text { Trust }\end{array}$ & Relational Trust \\
\hline $\begin{array}{l}\text { Trust of } \\
\text { citizens and } \\
\text { society in the } \\
\text { public sector }\end{array}$ & $\begin{array}{l}\text { - Define clear rights } \\
\text { and duties; dos and } \\
\text { don'ts; connecting to } \\
\text { citizens }\end{array}$ & $\begin{array}{l}\text { - Collect and } \\
\text { communicate data } \\
\text { on expectations, } \\
\text { perceptions, } \\
\text { satisfaction, trust }\end{array}$ & $\begin{array}{l}\text { - Willingness for } \\
\text { partnerships; } \\
\text { - Communicate shared } \\
\text { objectives }\end{array}$ \\
\hline $\begin{array}{l}\text { Trust of the } \\
\text { public sector in } \\
\text { society and its } \\
\text { citizens }\end{array}$ & $\begin{array}{l}\text { - Professional } \\
\text { bureaucrats } \\
\text { - State-of-law-based } \\
\text { charters to protect } \\
\text { rights of citizens } \\
\text { - Clear legal handling } \\
\text { of procedures } \\
\text { - Transparent due } \\
\text { process }\end{array}$ & $\begin{array}{l}\text { - Charters and } \\
\text { market-based } \\
\text { empowerment } \\
\text { - Benchmarks and } \\
\text { transparency on } \\
\text { performance } \\
\text { - Explicit quality } \\
\text { models }\end{array}$ & $\begin{array}{l}\text { - Co-design; co- } \\
\text { decide; co-produce; } \\
\text { co-evaluate } \\
\text { - Allowing volunteers }\end{array}$ \\
\hline $\begin{array}{l}\text { Trust within the } \\
\text { public sector }\end{array}$ & $\begin{array}{l}\text { - Internal loyalty } \\
\text { - Equilibrated } \\
\text { judgements of } \\
\text { process and } \\
\text { performance }\end{array}$ & $\begin{array}{l}\text { - Performance moni- } \\
\text { toring } \\
\text { - Performance budget- } \\
\text { ing/cost account- } \\
\text { ing/performance } \\
\text { auditing } \\
\text { - Contracts } \\
\text { - Balancing distrust } \\
\text { with more indicators, } \\
\text { standards and audits }\end{array}$ & $\begin{array}{l}\text { - Partnerships within } \\
\text { the public sector }\end{array}$ \\
\hline $\begin{array}{l}\text { Best Matching } \\
\text { Model }\end{array}$ & $\begin{array}{l}\text { Hierarchy: (Neo) } \\
\text { Weberian State (NWS) }\end{array}$ & $\begin{array}{l}\text { Performance and } \\
\text { market: New Public } \\
\text { Management (NPM) }\end{array}$ & $\begin{array}{l}\text { Networks: New Public } \\
\text { Governance (NPG) }\end{array}$ \\
\hline
\end{tabular}

Even if a clear attribution of trust bases and pure models is not always possible, there seems to be an inclination for institutional trust regimes to have a certain match with Neo-Weberian State systems, for calculus-based trust regimes to be linked to New Public Management models, and for relational trust systems to be connected to New Public Governance models. 


\section{Some conclusions}

Understanding trust and public administration should be looked at from a "Logic of consequences" and from a "Logic of appropriateness". Linking performance and trust in the three models we described seems to suggest that a logic of consequences is dominating. Both logics may lead to trust, but both are necessary and neither is sufficient alone.

It is possible to distinguish high- and low-trust societies (Fukuyama 1995), which may carry over into the operations of the civil service. However, the level is also a cultural issue, which makes it difficult to compare countries and even more to transfer practices from a high-trust country to a low-trust country. It would be difficult e.g. to transfer measures for trust-building and trust-keeping from New Zealand to Norway. Norway is one case where the attributes of trust have been maintained, including the civil service (Christensen and Lægreid 2005). "Relations between political and managerial executives have traditionally been defined in formal hierarchical terms, but have in reality been trust-based, with little external and formal steering devices. This trust-based feature is a strong overall feature of the system, also covering the political-administrative leaderships' relations to different professional groups" (Christensen, Lægreid and Stigen 2006, 116).

This brings us to some scientific conclusions which have an impact on practice and programmes for change and improvement, especially in times of crisis.

First, one should not maximise trust but optimise it, as a function of the cultural contingencies. Some distrust may even be functional and keep a tension for a reform agenda.

Second, even more important than a trust level is its fluctuation in time, in the short run, but also in the long run. This comparison in time should be complemented with comparisons with other actors in society from the private and the notfor-profit sector. Stereotypes can be corrected through these surveys, e.g. the public sector is not the least trusted in society.

Third, trust is a cause, an objective, a driver and a leverage. It is important to keep trust on the reform agenda in an explicit way. For each reform, the question should be asked what the impact could be or should be on trust, since it is easier to lose trust than to regain it.

Fourth, improving service delivery is necessary but not sufficient for trust. Good performance does not necessarily lead to more trust, but bad performance certainly will erode trust. There is a need to focus on external services for the trust of citizens in the public sector and vice versa, and on internal services for internal trust. This should take organisations, policy fields, and whole-of-government approaches. 
In choosing trust regimes, it is important to make explicit if there is an emphasis on a logic of consequences which refers to a causality and results where elements such as e.g. inputs, HRM, budget practices, regulatory management, policy instruments etc. result in performance and trust; or if there is rather an emphasis on the logic of appropriateness with values and identity which leads to a direct focus on integrity, open and responsive government, and transparency, leading to performance and trust.

Choosing a Trust-Regime (based on institution, calculus or relations) implies choosing different public-sector reforms (matching NWS, NPM or NPG) to realise a level which fits the culture of an organisation.

\section{References}

Bouckaert, Geert and John Halligan. 2008. Managing Performance, International Comparisons. London: Routledge.

Bouckaert, Geert, Geert Voets, Dries De Herdt. 2011. Local Government in the EU at a Glance: Survey Analysis. Working Paper SBOV, Leuven.

Christensen, T. and P. Lægreid. 2005. "Trust in Government: The Relative Importance of Service Satisfaction, Political Factors and Demography." Public Performance and Management Review 28 (4), 478-511.

Christensen, T., P. Lægreid and I. M. Stigen. 2006. "Performance Management and Public Sector Reform: The Norwegian Hospital Reform." International Public Management Journal 9 (2), 1-27.

Fukuyama, F. 1995. Trust: The Social Virtues and the Creation of Prosperity. New York: Free Press.

Halligan, J. and G. Bouckaert. 2009. "Performance and Trust: Developmental Paths and Optional Directions." In P. G. Roness and H. Sætren (eds). Change and Continuity in Public Sector Organizations: Essays in Honour of Per Logreid. Bergen, Norway: Fagbokforlaget, 257-277.

Lewicki, Roy J. and Barbara Benedict Bunker. 1996. "Developing and Maintaining Trust in Work Relationships." In Roderick M. Kramer and Tom R. Tyler (eds). Trust in Organisations: Frontiers of Theory and Research. Thousand Oaks, Ca.: Sage, 114-139.

Muthusamy, Senthil K. and Margaret A. White. 2005. "Learning and Knowledge Transfer in Strategic Alliances: A Social Exchange View." Organization Studies 26, 415-441.

OECD. 2011a. The Call for Innovative and Open Government: An Overview of National Initiatives. Paris: OECD. 
OECD. 2011b. Government at a Glance 2011. Paris: OECD.

OECD. 2005. Public Sector Reform: The Way Forward. Paris: OECD.

Pollitt, Christopher and Geert Bouckaert. 2011. Public Management Reform: A Comparative Analysis of NPM, the Neo-Weberian State, and New Public Governance. $3^{\text {rd }}$ expanded edn. Oxford: Oxford University Press.

Rousseau, Denise M., Sim B. Sitkin, Ronals S. Burt and Colin Camerer. 1998. "Introduction to Special Topic Forum. Not so Different after all: A Cross-Discipline View of Trust." Academy of Management Review 23 (3), 393-404.

Sako, Mari. 1992. Prices, Quality and Trust: Inter-Firm Relations in Britain \& Japan. Cambridge: Cambridge University Press.

Van de Walle, Steven. 2011. "NPM: Restoring the Public Trust through creating Distrust?” In Tom Christensen and Per Lægreid (eds). The Ashgate Research Companion to New Public Management. Farnham, Surrey: Ashgate, 309-320.

Van de Walle, Steven, Steven Van Roosbroek and Geert Bouckaert. 2005. Strengthening Trust in Government: What Role for Government in the $21^{\text {st }}$ Century: Annex: Data on trust in the public sector. Analytical annex prepared for the OECD meeting of the Public Governance Committee at ministerial level, Rotterdam, 27-28 November 2005. Paris: OECD. (also available in French).

Van Dooren, Wouter, Geert Bouckaert and John Halligan. 2010. Performance Management in the Public Sector. London: Routledge. 